\title{
Epidemiology Profile of Traumatic Spine Injury of a Spinal Cord Service in the State of Espírito Santo
}

\section{Avaliação do perfil epidemiológico do traumatismo raquimedular de um serviço de coluna do estado do Espírito Santo}

\author{
Gabriela Scopel ${ }^{1}$ Charbel Jacob Júnior ${ }^{2}$ Marcus Alexandre Novo Brazolino ${ }^{2}$ Igor Machado Cardoso ${ }^{2}$ \\ José Lucas Batista Júnior ${ }^{2}$ Luciana Carrupt Sogame ${ }^{1}$ Thiago Cardoso Maia ${ }^{2}$ Tadeu Gervazoni Debom² \\ ${ }^{1}$ Department of Orthopedy, Santa Casa de Misericórdia, Vitória, \\ ES, Brazil \\ 2 Department of Spinal Cord Surgery, Santa Casa de Misericórdia, \\ Vitória, ES, Brazil

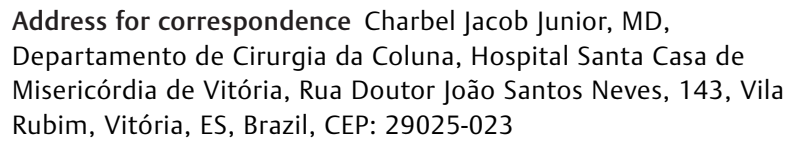

Address for correspondence Charbel Jacob Junior, MD, Departamento de Cirurgia da Coluna, Hospital Santa Casa de Misericórdia de Vitória, Rua Doutor João Santos Neves, 143, Vila Rubim, Vitória, ES, Brazil, CEP: 29025-023 \\ (e-mail: Charbeljacob@hotmail.com).
}

Arq Bras Neurocir 2018;37:101-104

\begin{abstract}
Keywords

- epidemiology

- spinal cord injuries

\section{Resumo}

Objective To analyze the epidemiological profile of patients with traumatic spinal cord injury $(\mathrm{SCl})$ undergoing surgical procedures in the state of Espírito Santo, Brazil. Methods A cross-sectional, descriptive study was performed based on the analysis of 70 medical records of patients who underwent surgery due to traumatic $\mathrm{SCl}$ in the state of Espírito Santo, Brazil.

Results Males comprised $79 \%$ of the patients. The average age of the occurrence of the traumatic $\mathrm{SCl}$ was 44 years; automobile accidents were the main cause of trauma (44\%). Half of the patients had lesions in the cervical region, and $46 \%$ were classified as Frankel A, according to the Frankel scale. In the first 60 days after surgery, the main complication presented by the patients was urinary tract infection (UTI). Half of the patients were from the metropolitan area.

Conclusion Patients undergoing surgery for traumatic $\mathrm{SCl}$ in the state of Espírito Santo are predominantly men, with a mean age of 44 years, with cervical spine injury due to car accidents, from the metropolitan area, and whose main complication was UTI.

Objetivo Analisar o perfil epidemiológico dos pacientes com traumatismo raquimedular (TRM) submetidos a procedimentos cirúrgicos no estado do Espírito Santo, Brasil. Métodos Foi realizado um estudo transversal e descritivo, baseado na análise de 70 prontuários de pacientes submetidos a procedimento cirúrgico em decorrência de TRM no estado do Espírito Santo, Brasil.

Resultados Um total de $79 \%$ dos pacientes era do sexo masculino. A média de idade foi de 44 anos, sendo acidente automobilístico a causa principal de trauma (44\%). Metade dos pacientes apresentou lesão em região cervical, e $46 \%$ foram classificados
\end{abstract}

received

September 25, 2015

accepted

November 23, 2015

published online

January 22, 2016

January 22, 2016 
como Frankel A, de acordo com a escala Frankel. Nos primeiros 60 dias após a cirurgia, a principal complicação apresentada pelos pacientes foi infecção do trato urinário (ITU). Metade dos pacientes era proveniente da região metropolitana do estado.

Palavras Chave

- epidemiologia

- traumatismo raquimedular
Conclusão Os pacientes submetidos a procedimento cirúrgico por TRM no estado do Espírito Santo são predominantemente homens, com idade média de 44 anos, lesão da coluna cervical por acidente automobilístico, e provenientes da região metropolitana. A principal complicação apresentada foi ITU.

\section{Introduction}

Traumatic spinal cord injuries (SCIs) comprise spinal injuries in any part of the spinal column that contains the spinal cord. $^{1}$ They may result in motor, sensory, sphincter and autonomic dysfunction below the level of the lesion. The evaluation of neurological lesions is established by the Frankel scale, and they are graded as complete lesion, incomplete lesion and normal function. ${ }^{2}$ The severity of the lesion is classified as complete or incomplete according to the norms established by the American Spinal Cord Injury Association (ASIA), the complete lesion corresponding to the total absence of motor and sensory functions below the level of the lesion. ${ }^{3}$

The complications of SCIs include pulmonary complications, spasms, pain and urinary tract infections (UTIs), among others. The most common cause of death in these patients is pneumonia. ${ }^{4,5}$ Several studies indicate that UTI is the most common complication, followed by pain and spasms. ${ }^{3}$ The prevalence of pain after a SCI varies considerably, and is seen in about one-half to two-thirds of the patients. $^{5}$

There is no official notification of SCI cases. However, it is estimated that the annual incidence is 21 patients per million inhabitants. ${ }^{6}$ In developing countries, the incidence is 25.5 cases per million every year. ${ }^{7}$ Men are most affected, ${ }^{7,8}$ corresponding to $82.8 \%$ of all cases. The average age is 32.4 years in developing countries. ${ }^{7}$ Since SCIs affect mostly young and economically active people, they end up interrupting the individual's professional activity at the peak of the potential for economic gain, generating a high cost to society. ${ }^{7,9}$

The two main causes of SCIs pointed out in international studies are automobile accidents and falls (41.4\% and 34.9\% respectively), followed by violence and sports accidents. ${ }^{7,10}$ National studies diverge from classic statistics, having gunshot wounds in second place among the causes of SCIs, followed by falls and cold steel wounds. ${ }^{9}$

The adequate time for surgical intervention after a SCI remains controversial. Several studies did not show a clear improvement in the neurological prognosis; however, there is evidence of clinical safety in early surgical intervention. ${ }^{11-14}$

Brazil's currently available epidemiological data are relatively scarce and conflicting with the literature. ${ }^{9,15}$ Therefore, we have proposed to evaluate the epidemiological profile of patients with SCIs submitted to a surgical procedure in the state of Espírito Santo.

\section{Materials and Methods}

A cross-sectional, descriptive study was performed based on the analysis of 70 records of patients submitted to a surgical procedure due to SCIs in the state of Espírito Santo from February 2011 to February 2015.

The selected patients were admitted to several private and public hospitals in the state of Espírito Santo, and were referred by the central regulation of beds or by spontaneous demand. The following variables were analyzed: age, gender, patient origin, fracture level, neurological level, trauma mechanism and complications in the first 60 days after surgery.

Data were collected and distributed in projections using the Microsoft Excel (Microsoft Corporation, Redmond, WA, US) software to evaluate the distribution of each analyzed piece of data. The percentiles and absolute numbers of affection of each analyzed event were considered.

\section{Results}

A total of 70 records were analyzed, and $79 \%$ of them corresponded to male patients $(n=55)$. The mean age was 44 years, ranging from 14 to 75 years. Young people (20-24 years old) constituted $32 \%$ of the cases, followed by adults (31-59 years old; $28 \%$ ); young adults ( $25-30$ years old; $20 \%$ ); adolescents (10-19 years old; $12 \%$ ); and the elderly (over 60 years old; $8 \%$ ) ( - Table 1 ).

Among the trauma mechanisms, automobile accidents represented $44 \%$ of the total, followed by gunshot wounds (GSWs), which corresponded to $27 \%$ of the cases. Falls and dives occupied the third and fourth places respectively (-Table 2). Half of the patients in the sample presented lesions in the cervical region, and $26 \%$, in the thoracolumbar region. The thoracic segment was the third most affected

Table 1 Sample distribution by age

\begin{tabular}{|l|l|l|}
\hline Age (years) & $\begin{array}{l}\text { Classification (Brazilian } \\
\text { Ministry of Health) }\end{array}$ & $\%$ \\
\hline $10-19^{*}$ & Adolescent & 12 \\
\hline $20-24^{*}$ & Young & 32 \\
\hline $25-30^{*}$ & Young adult & 20 \\
\hline $31-59^{*}$ & Adult & 28 \\
\hline$\geq 60^{*}$ & Elder & 08 \\
\hline
\end{tabular}

Note: *Standard deviation. 
Table 2 Sample distribution by injury mechanism

\begin{tabular}{|l|l|l|}
\hline Injury mechanism & Total of patients (70) & $\%$ \\
\hline Gunshot wound & 19 & 27 \\
\hline Automobile accident & 31 & 44 \\
\hline Fall & 15 & 22 \\
\hline Diving & 5 & 7 \\
\hline
\end{tabular}

site, and the lumbar segment was affected in only $4 \%$ of the cases ( - Table $\mathbf{3}$ ).

According to the Frankel scale, $46 \%$ of the patients were classified as Frankel A. Frankel C was the second most frequent classification, with 19 cases, followed by Frankel E, B and D, with 9, 8 and 2 cases respectively (-Table 4 ).

During the first 60 days after surgery, the patients were checked for the presence of complications. Out of the 70 patients, 36 had complications during this period. The most frequent was UTI, with 18 cases, followed by the presence of pressure ulcer, which occurred in 10 cases. A total of 4 patients developed pneumonia, and 1 had cardiac complications. During the first 2 months after surgery, 3 patients had an association of UTI and eschar (- Table 5 ).

As to the origin, 35 patients came from the metropolitan region of the state capital of Vitória. The others came from the central region (18 patients), the southern region (4 patients) and the northern region ( 7 patients) of the State of Espírito Santo. A total of 6 patients came from other states ( - Table 6 ).

\section{Discussion}

Spinal cord injury is a disease that presents a devastating potential not only for patients and families, but also for the economy, since it involves a huge financial health cost. ${ }^{15}$

Table 3 Sample distribution by injury level

\begin{tabular}{|l|l|l|}
\hline Injury level & Total of patients (70) & \% \\
\hline Cervical & 35 & 50 \\
\hline Thoracic & 14 & 20 \\
\hline Thoracolumbar* & 19 & 26 \\
\hline Lumbar & 2 & 4 \\
\hline
\end{tabular}

Note: *Transition region between the thoracic and lumbar regions (fractures of D11 to L1).

Table 4 Classification of spinal cord injuries according to the Frankel scale

\begin{tabular}{|l|l|l|}
\hline Frankel & Total of patients (70) & $\%$ \\
\hline A & 32 & 46 \\
\hline B & 8 & 11 \\
\hline C & 19 & 27 \\
\hline D & 2 & 3 \\
\hline E & 9 & 13 \\
\hline
\end{tabular}

Table 5 Sample distribution of clinical complications within the first 60 days after surgery

\begin{tabular}{|l|l|}
\hline $\begin{array}{l}\text { Clinical complications until } \\
\text { 60 days postsurgery }\end{array}$ & Total of patients (70) \\
\hline UTI & 18 \\
\hline Pressure ulcer & 10 \\
\hline Pneumonia & 4 \\
\hline Cardiac & 1 \\
\hline UTI and eschar & 3 \\
\hline
\end{tabular}

Abbreviation: UTI, urinary tract infection.

An adequate analysis of the distribution and prevalence of SCIs is of paramount importance for the planning and development of strategies to approach polytrauma and for the implementation of measures to increase population awareness.

In the present study, there was a predominance of male patients (79\%), which in line with the data from the literature. ${ }^{7-9,15,16}$ The mean age of the most affected patients in developing countries is 32.4 years old, according to a study by Rahimi-Movaghar et al. ${ }^{7}$ The average age found in the present study, was higher: 44 years old. However, considering the classification of the Brazilian Ministry of Health, both averages place these patients within the age group of adults (31-59 years old).

Fractures occurred mostly at the cervical level (50\%), which similar to in the findings of national and international studies. $^{8,9,17}$ About $4.5 \%$ of the patients in one study had more than one fracture at different medullar levels. ${ }^{18}$ Therefore, due to the high frequency of cervical fractures and their great impact on the neurological status and the quality of life of the patients, protection of the cervical spine in the initial care becomes essential.

Regarding the severity of the neurological deficit, the majority of patients (46\%) were classified as Frankel A, due to the absence of any motor or sensory function below the lesion. This neurological picture was also observed in national studies. ${ }^{15}$

Table 6 Distribution of the sample according to the origin of the patient with spinal cord injury

\begin{tabular}{|l|l|l|}
\hline Patient origin & $\begin{array}{l}\text { Total of } \\
\text { patients (70) }\end{array}$ & $\%$ \\
\hline $\begin{array}{l}\text { Metropolitan area of the } \\
\text { capital city of Vitória }\end{array}$ & 35 & 50 \\
\hline $\begin{array}{l}\text { Central region of the } \\
\text { State of Espírito Santo }\end{array}$ & 18 & 25 \\
\hline $\begin{array}{l}\text { Southern region of the } \\
\text { State of Espírito Santo }\end{array}$ & 4 & 5 \\
\hline $\begin{array}{l}\text { Northern region of the } \\
\text { State of Espírito Santo }\end{array}$ & 7 & 11 \\
\hline Other states & 6 & 9 \\
\hline
\end{tabular}


The two main causes of SCIs in the present study (automobile accidents and gunshot wounds) are similar to those found in the epidemiological analysis of national data. ${ }^{9}$ However, this result differs from the international figures, in which falls appear as the second main cause of SCIs. ${ }^{7,10}$ In developed countries, the proportion of trauma by automobile accident is stable, with a tendency to decrease, which is justified in part by the better infrastructure and greater safety provided by their automotive vehicles. ${ }^{19}$

Among the complications, UTI was the most frequent, present in $26 \%$ of the cases with complications, a result similar to those reported in several international studies. ${ }^{3}$ Pagliacci et $\mathrm{al}^{20}$ suggest that $53.7 \%$ of SCI patients presented urologic complications in the first 6 months posttrauma.

The origin of the patients was evaluated according to the macro-regional division of the state of Espírito Santo, ${ }^{21}$ with the majority of patients submitted to surgery for traumatic $\mathrm{SCI}(75 \%)$ coming from the metropolitan region of the capital city of Vitória and the central region of the state of Espírito Santo (-Table 6). The southern region of the state had less referrals, probably due to the proximity to the city of Rio de Janeiro. A total of $9 \%$ of the patients came from another state (southern region of the state of Bahia), since the closest reference center for these patients is located in Vitória.

\section{Conclusion}

The patients submitted to a surgical procedure for $\mathrm{SCI}$ in the state of Espírito Santo are predominantly men, with a mean age of 44 years, cervical spine injury due to automobile accidents, classified as Frankel A, and originally from the metropolitan regionof the city of Vitória. The main complication presented was UTI.

\section{Conflicts of Interest}

The authors declare that there are no conflicts of interest in the present work.

\section{References}

1 Silveira PR. Trauma raquimedular: diagnóstico e tratamento nas emergências. Rev Bras Med 2000;78:17-37

2 Frankel HL, Hancock DO, Hyslop G, et al. The value of postural reduction in the initial management of closed injuries of the spine with paraplegia and tetraplegia. I. Paraplegia 1969;7(03):179-192

3 Yang R, Guo L, Wang P, et al. Epidemiology of spinal cord injuries and risk factors for complete injuries in Guangdong, China: a retrospective study. PLoS One 2014;9(01):e84733
4 Sousa EPD, Araujo OF, Sousa CLM, Muniz MV, Oliveira IR, Neto NGF. Principais complicações do Traumatismo Raquimedular nos pacientes internados na unidade de neurocirurgia do Hospital de Base do Distrito Federal. Com. Ciênc Saúde (Porto Alegre) 2013;24 (04):321-330

5 Pereira CU, Carvalho LFP, Santos EAS. Complicações clínicas do traumatismo raquimedular: pulmonares, cardiovasculares, geniturinárias e gastrointestinais. Arq Bras Neurocir 2010;29(03):110-117

6 Botelho RV, Albuquerque LDG, Junior RB, Júnio AA. Epidemiology of traumatic spinal injuries in Brazil: systematic review. Arq Bras Neurocir 2014;33(02):100-106

7 Rahimi-Movaghar V, Sayyah MK, Akbari H, et al. Epidemiology of traumatic spinal cord injury in developing countries: a systematic review. Neuroepidemiology 2013;41(02):65-85

8 Stephan K, Huber S, Häberle S, et al; TraumaRegister DGU. Spinal cord injury-incidence, prognosis, and outcome: an analysis of the TraumaRegister DGU. Spine J 2015;15(09):1994-2001

9 Pereira CU, Jesus RM. Epidemiologia do Traumatismo Raquimedular. J Bras Neurocirurg 2011;22(02):26-31

10 Hagen EM, Rekand T, Gilhus NE, Grønning M. Traumatic spinal cord injuries-incidence, mechanisms and course. Tidsskr Nor Laegeforen 2012;132(07):831-837

11 Cadotte DW, Fehlings MG. Spinal cord injury: a systematic review of current treatment options. Clin Orthop Relat Res 2011;469(03): 732-741

12 Albert TJ, Kim DH. Timing of surgical stabilization after cervical and thoracic trauma. Invited submission from the Joint Section Meeting on Disorders of the Spine and Peripheral Nerves, March 2004. J Neurosurg Spine 2005;3(03):182-190

13 Vaccaro AR, Daugherty RJ, Sheehan TP, et al. Neurologic outcome of early versus late surgery for cervical spinal cord injury. Spine 1997;22(22):2609-2613

14 Rutges JP, Oner FC, Leenen LP. Timing of thoracic and lumbar fracture fixation in spinal injuries: a systematic review of neurological and clinical outcome. Eur Spine J 2007;16(05):579-587

15 Júnior MFS, Bastos BPR, Jallageas DN, Medeiros AAA. Perfil epidemiológico de 80 pacientes com traumatismo raquimedular, internados no Hospital do Pronto-Socorro Municipal de Belém, PA, no período de janeiro a setembro de 2002. J Bras Neurocirurg 2002;13(03):92-98

16 Rahimi-Movaghar V, Saadat S, Rasouli MR, et al. Prevalence of spinal cord injury in Tehran, Iran. J Spinal Cord Med 2009;32(04): 428-431

17 Pickett GE, Campos-Benitez M, Keller JL, Duggal N. Epidemiology of traumatic spinal cord injury in Canada. Spine 2006;31(07):799-805

18 Calenoff L, Chessare JW, Rogers LF, Toerge J, Rosen JS. Multiple level spinal injuries: importance of early recognition. AJR Am J Roentgenol 1978;130(04):665-669

19 Lee BB, Cripps RA, Fitzharris M, Wing PC. The global map for traumatic spinal cord injury epidemiology: update 2011, global incidence rate. Spinal Cord 2014;52(02):110-116

20 Pagliacci MC, Franceschini M, Di Clemente B, Agosti M, Spizzichino L; GISEM. A multicentre follow-up of clinical aspects of traumatic spinal cord injury. Spinal Cord 2007;45(06):404-410

21 www.es.gov.br/Banco\%20de\%20Documentos/mapas/Divisao-Regional_Macrorregioes.jpg 